\title{
Statyba
}

\section{THEORY OF FUZZY SETS IN DECISION-MAKING SYSTEMS OF BUILDING MANAGEMENT}

\section{P. Gaučas \& E. K. Zavadskas}

To cite this article: P. Gaučas \& E. K. Zavadskas (2000) THEORY OF FUZZY SETS IN DECISION-MAKING SYSTEMS OF BUILDING MANAGEMENT, Statyba, 6:4, 237-246, DOI: 10.1080/13921525.2000.10531595

To link to this article: https://doi.org/10.1080/13921525.2000.10531595

曲 Published online: 26 Jul 2012.

Submit your article to this journal

III Article views: 68 


\title{
NEAPIBRĖ̌̌tUUU AIBIŲ TEORIJOS TAIKYMAS PASTATU VALDYMO SPRENDIMŲ PRIĖMIMO SISTEMOMS
}

\author{
P. Gaučas, E. K. Zavadskas
}

\section{Vilniaus Gedimino technikos universitetas}

\section{Ivadas. Sprendimo prièmimo problematika}

Pastatų valdymo, t. y. sprendimu prièmimo bet kuriuo pastato egzistavimo ciklo momentu efektyvumas priklauso nuo informacijos lygio apie juos veikiančius kiekybinius ir kokybinius veiksnius. Kiekybiniams veiksniams suteikiame skaitines reikšmes, jas vertiname taikydami iprastinius matematinius metodus, tuo tarpu kokybiniams veiksniams suteikti skaitines reikšmes dažnai galime tik remdamiesi savo intuicija, žiniomis ir patirtimi.

Analizès, sprendimo prièmimo efektyvumo lygis labai priklauso nuo informacijos, apibūdinančios analizès objektą ar požiūrị i ji, tikslumo. Kaip teigiama [1], aukščiausias informacijos tikslumo lygis yra pasiekiamas tada, kai ją galima išreikšti skaičiais. Kai kuriuos kriterijus galima tiesiogiai išreikšti fiziniais dydžiais (kilogramais, metrais, laipsniais ir pan.), kitus kriterijus, tokius, kaip estetika, komfortiškumas, darbo saugumas, funkcionalumas ir pan., galima išreikšti santykinai (balais, procentais ir pan.) [1].

Sprendimų prièmimo uždaviniai statyboje pastaraisiais metais dèl greitos techninès pažangos darosi vis sudètingesni. Sprendimai apibūdinami daugybe ịvairiausių išsišakojusių ir tarpusavyje susipynusiu kriterijų [2]. Sprendimams daro itaką suinteresuotos grupès, kuriu poreikiai ir tikslai skiriasi ir kurios turi subjektyvią nuomonę apie vieną ar kitą pastato savybę. Taigi priimant sprendimus atsižvelgiama i suinteresuotų grupių tikslus bei galimybes [1]. Tačiau turimi tikslai, vertinant galimybes bei aplinkybes, dažnai prieštarauja vieni kitiems [3].

Kai statant pastata reikia priimti sprendimą, siekiama esamomis sąlygomis minimaliu techninių ir ekonominių sąnaudụ garantuojant patikimumą ir aukštą kokybę. Taip susidaro prieštaringa situacija. Kokybès reikalavimai logiškai sietini su brangiai kainuojančiu realizavimu [4]. Taigi būtina sudaryti sprendimų modelị, leidžianti ivertinti konfliktines bei prieštaringas situacijas.

\section{Neapibrèžtų aibių teorijos esmè}

Priimant, analizuojant bei vertinant sprendimus išryškèja tendencija ignoruoti tokias sąvokas kaip neaiškumas, neapibrèžtumas, netikslumas ir pan. dèl ju nemokslinès ar iracionalios koncepcijos. Pasitaiko gausybè atveju, kai negalime išvengti neaiškios ir netikslios informacijos vertinimo. Kai reikia parinkti optimaly sprendimą (pvz., būsto variantą), jis turi maksimaliai atitikti strategiją apibūdinančius sprendimo gerumo kriterijus. Tačiau gerumo vertinimas nepaklūsta ,juoda balta“ logikai, o yra neapibréžta sąvoka. 1965 m. L. Zade pasiūlè neapibréžtuju aibių teoriją neaiškiu ir netiksliụ sąvokų, apibūdinančių ìvykius ar faktus, santykius tarp objektu ar veiksmų, analizei [5].

Klasikiniai sprendimy prièmimo modeliai teigia, kad šiuos modelius apibūdina toks požymis, kai optimalių arba galimų alternatyvų aibė yra griežtai atskirta nuo neoptimalių alternatyvų aibès. Tokiam griežtam apribojimui reikia nepaprastai tikslios informacijos, kas tik retais atvejais yra imanoma. Pavyzdžiui, sprendžiant, koks statybos objekto variantas yra geriausias, dažnai neturime visos (apibrèžtos) informacijos apie keliamus tikslus bei ju apribojimus (maksimali kokybè, bet minimali kaina). Kai nèra visos parametrų informacijos ir ivertinimų, nustatančiu statybos objektụ matmenis, sprendimų priemimo situacijos neapibrèžtumas yra pagristas [2].

Iki šiol atliekant investicinius skaičiavimus buvo atsižvelgiama tik i neaiškumą tam tikrų ivykiụ pradžios ir būklès atžvilgiu (rizikos būklè). Buvo remiamasi prielaida, kad galimų ivykiu arba būkliụ kiekis yra vienareikšmiškai apibréžtas. Tačiau tai neturi reikš- 
mès nevienareikšmèms nuostatoms: elementu, kuriems pastaroji prielaida galioja, kiekio neimanoma tiksliai atskirti nuo elementų, kuriems prielaida neturi itakos, kiekio [4].

\section{Neapibrèžtụjų aibiụ taikymo prielaidos priimant sprendimus}

Kaip jau buvo minèta, siekiant ivvertinti alternatyvas (priimti sprendimą) atsižvelgiant i keliamus tikslus, galimybes bei aplinkybes, susiduriama su konfliktine situacija. Šiuo atveju sprendimą galima suprasti ji suvokiant kaip konfliktą žaidimų teorijoje, kur informacija ne visada yra apibrèžta. Šiai problemai spręsti galime taikyti neapibrežtų aibių teoriją, dèl ko yra galima žaidimo elementus formuluoti neapibrèžtai ir sudaryti naują modeli. Siekiant juertinti konfliktinius keliamu tikslų, galimybiu bei aplinkybiu santykius, sistemos itakos veiksniai padalyti $\mathfrak{i}$ dvi grupes - vadinamuosius vidinius ir išorinius sistemos itakos veiksnius. Šios dvi grupès atspindi pagrindinius sprendimo prièmimo tikslus. Pirmoji grupe (vidiniai itakos veiksniai) nusako, ko sprendimų prièmèjas siekia (pvz., maksimizuoja kokybę), antroji grupé nusako, ką sprendimu prièmejjas turètu ivertinti kaip apribojimą (pvz., minimizuoja kainą). Konfliktinè situacija tarp šiụ dvieju grupių nusakoma kaip žaidimas (vienas tikslas maksimizuoti kokybę, kitas tikslas - minimizuoti kainą). Faktas, kad statybos objektą iš vienos pusès charakterizuoja kokybès bei užsakovo poreikius apibūdinantys veiksniai (vidiniai veiksniai) ir iš kitos - objekto projektavimo, statybos, eksploatavimo išlaidos, techniniai reikalavimai (išoriniai veiksniai), yra sisteminio požiūrio pagrindas. Čia susidaro tarpusavio priklausomybès tarp vidinių ir išorinių veiksniu [3].

\section{Neapibrèžtųjų aibių vertinimo modelio sudary- mas}

Neapibrėžtuju aibių teorija leidžia matematiškai aprašyti ir valdyti neapibréžtus elementus. Atsakymas i klausimą, priklauso elementas neapibrèžtajai aibei ar ne, nepatenka atitinkamai i taip/ne sprendimą, bet reikia laipsniško sprendimo nustatant jo priklausomumą.

Neapibrèžtujų aibių teorijoje nèra aiškios ribos tarp elementu priklausomumo (reikšmé 1) ir nepriklausomumo (reikšmè 0) apibrèžtajai aibei, kuri būdinga kla- sikiniam aibès supratimui. Elemento $x$ priklausomumą aibei $A$ galime apibrèžti reikšmèmis, kurios yra tarp 0 ir 1. Elemento $x$ priklausomumo laipsnis aibei $A$ neapibrèžtosiose aibėse aprašomas priklausomumo funkcija $\mu_{A}(x)$, kuri suteikia elementui $x$ priklausomumo reikšmes intervalu nuo 0 iki $1[6,7]$.

$$
A=\left\{\left(x, \mu_{A}(x)\right) / x \in X\right\} .
$$

$\mu_{A}(x)$ elemento $x$ priklausomumo neapibréžtajai aibei A reikšmè.

Paprastai $A$ reikšmių sritis apribota uždaruoju intervalu $[0,1]$. Kai kuriais atvejais intervalas gali būti ir kitoks. Alternatyvu erdvès subjektyvus dalijimas i klases vyksta pasirenkant tris taškus $a_{o}, a_{d}, a_{m}$, kuriems imamos priklausomumo reikšmès $\mu\left(a_{o}\right)=0, \mu\left(a_{d}\right)=0,5$, $\mu\left(a_{m}\right)=1$. Alternatyvų aibè suskirstoma i tokias keturias sritis:

$$
\begin{aligned}
& B_{1} \Leftrightarrow x_{i j} \leq a_{j}, \\
& B_{2} \Leftrightarrow a_{m} \leq x_{i j}, \\
& B_{3} \Leftrightarrow a_{o}<x_{i j} \leq a_{d}, \\
& B_{4} \Leftrightarrow a_{d}<x_{i j} \leq a_{m} .
\end{aligned}
$$

Elementų priklausomumo reikšmès randamos taikant lygybių sistemą [3]:

$\mu_{j}(a)=\left\{\begin{array}{rll}0, & \text { kai } & a \leq a_{o}, \\ A a^{3}+B a^{2}+C a+D, & \text { kai } & a_{o} \leq a \leq a_{d}, \\ E a^{3}+F a^{2}+G a+H, & \text { kai } & a_{d} \leq a \leq a_{m}, \quad(1) \\ 1, & \text { kai } & a_{m} \leq a .\end{array}\right.$

Koeficientai $(A, \ldots, H)$ apskaičiuojami taikant lygčių sistemą:

$$
\begin{aligned}
& A a_{o}^{3}+B a_{o}^{2}+C a_{o}+D=0, \\
& A a_{D}^{3}+B a_{D}^{2}+C a_{D}+D=0,5, \\
& E a_{D}^{3}+F a_{D}^{2}+G a_{D}+H=0,5, \\
& E a_{m}^{3}+F a_{m}^{2}+G a_{m}+H=1, \\
& 3 A a_{o}^{2}+2 B a_{o}+C=0, \\
& 3 E a_{m}^{2}+2 F a_{m}+G=0, \\
& 3 A a_{D}^{2}+2 B a_{D}+C-E a_{D}^{2}-2 F a_{D}-G=0, \\
& 6 A a_{D}+2 B-6 E a_{D}-2 F=0 .
\end{aligned}
$$

Šių lygčiụ sudarymo sąlygos bei reikalavimai nuodugniai aprašyti literatūros šaltinyje [3]. 
Priklausomumo funkcija turi ịvykdyti sąlygą $\mu_{j}\left(a_{j}\right) \in[0,1]$, tačiau esant $a_{d}$ arti $a_{o}$ ar $a_{m}, \mu_{j}$ reikšmès išeina už intervalo $[0,1]$ ribų, todèl turi būti jvykdyta ši nelygybè:

$$
-1+\sqrt{2} \leq \frac{\left|a_{m}-a_{d}\right|}{\left|a_{d}-a_{o}\right|} \leq 1+\sqrt{2} .
$$

Prieštaringa arba konfliktinè situacija egzistuoja ne tiesiogai tarp keliamų tikslu, galimybių bei aplinkybių, bet tarp sprendimų prièmèjo ir priešininko, atvaizduojamo galimybèmis ar aplinkybèmis. Sprendimụ prièmejjas turi ivertinti statybos variantus, atsižvelgdamas $\mathrm{i}$ vidinius veiksnius, t. y. keliamus tikslus, kuriuos jis siekia maksimizuoti. Tačiau to nepakanka sprendimui gauti. Toks sprendimas tèra tik vienas elementas sprendimu žaidime, būtent I žaidèjo strategija. Priešininkas (ir kartu II žaidejjas) formuoja savo strategiją atsižvelgdamas $i$ išorinius veiksnius. I žaidèjas disponuoja strategiju aibe ir informacija, liečiančia II žaidejo strategiju aibę. Apie pastarojo elgesi ir ketinimus I žaidèjas informacijos neturi. Tačiau tai vyksta ne siekiant maksimizuoti laimèjimo naudą ar siekiant nugalèti priešininką, o norint pasiekti žinomą užsibrèžtą tikslą.

Iš klasikinès aibių teorijos yra žinoma, kad dviejų tikslo komponentụ ryšiui egzistuoja operatoriai „ir“ ir ,arba“. Abu operatoriai apibūdinami kaip sprendimo tikslo jungiamieji ir skiriamieji ryšiai. Esant jungiamajam ryšiui tik iš dalies pasiektas tikslas yra priežastis to, kad bendras tikslas irgi pasiekiamas tik iš dalies, net jeigu kiti tikslai pasiekiami gerai. Esant skiriamajam tikslo ryšiui tik iš dalies pasiektas tikslas turès mažai itakos kitam siekiamam tikslui.

Dažniausiai jungiamajam ryšiui naudojamas minimumo operatorius, o skiriamajam ryšiui - maksimumo operatorius. Motyvas yra tas, kad minimumas ir maksimumas apibendrina loginius operatorius ,.ir" ir „arba“ $[6,8]$. Problemai spręsti tikslinè funkcija turi būti transformuota i priklausomumo funkciją, kuri rodo tikslinès funkcijos pasiekimo laipsni skirtingu ieškomų reikšmių atžvilgiu. Šiai priklausomumo funkcijai sudaryti būtinos dvi apibréžtos tikslinès funkcijos reikšmès: reikšmė, apatinè riba, kuri negali būti peržengta (priklausomybès reikšmė - nulis), ir maksimaliai pasiekiama reikšmé (priklausomybès reikšmé lygi vienetui) [4].
Kelių konfliktinių tikslinių funkcijų (žaidimų teorijoje tai suvokiant kaip dviejų žaideju strategijas) integracija gali būti jivykdyta vadinamuoju minimumo operatoriumi. Apskritai jungiant dvi priklausomumo funkcijas $\mu_{A}(x)$ ir $\mu_{B}(x)$ i funkcija $\mu_{C}(x)$, šis operatorius suteikia kiekvienai elemento $x$ reikšmei minimalią reikšmę, kurią priima viena iš šiu priklausomumo funkcijų $\left(\mu_{A}(x)\right.$ ir $\left.\mu_{B}(x)\right)$.

Jeigu, sprendžiant daugiatikslès optimizacijos problemą, taikomas minimumo operatorius, tai keliamas tikslas maksimizuoti minimalią priklausomybès reikšmę, kurią gauna viena iš priklausomumo funkcijų.

Dvieju neapibrèžtụjų aibių $A$ ir $B$ su priklausomumo funkcijomis $\mu_{A}$ ir $\mu_{B}$ pjūvio aibès priklausomumo funkcija $\mu_{A \cap B}$ (l pav.) apibrèžiama per minimumo operatoriy $[3,6]$ :

$$
\mu_{C}(x)=\mu_{A \cap B}(x)=\operatorname{Min}\left[\mu_{A}(x), \mu_{B}(x)\right]
$$

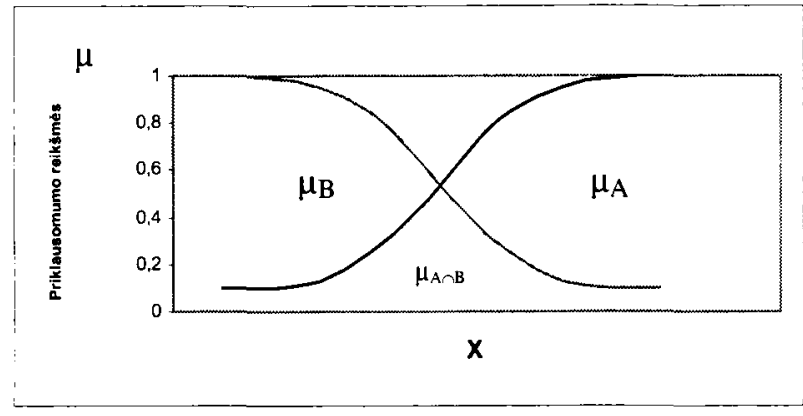

Dviejų neapibrèžtujų aibių $A$ ir $B$ su priklausomumo funkcijomis $\mu_{A}$ ir $\mu_{B}$ pjūvio aibès priklausomumo funkcijos $\mu_{A \cap B}$ grafinè interpretacija

Graphical interpretation of sections set dependent function of two $A$ and $B$ fuzzy sets with dependent functions $\mu_{A}$ and $\mu_{B}$

İvertinimas šioje neapibrėžtujų aibių teorijos versijoje vyksta trimis pakopomis, remiantis anksčiau išdestytais vertinimo modelio principais [3].

1 pakopa. Yra žinoma alternatyvu aibè. Šioje pakopoje šią aibę identifikuoja kriterijai, kurie kiekybiškai arba kokybiškai aprašo alternatyvas. Būtinas problemos transformavimas i palyginamają formą. Priklausomumo funkcija čia apskaičiuojama pagal (1)-(3). Tuo gaunama atitinkamai alternatyvai priklausomumo reikšmé pagal kiekvieną kriterijų. Tai yra igyvendinama tik vidinių veiksnių kriterijams. 
1 lentelè. Vidinių veiksnių priklausomumo reikšmių matrica

Table 1. Matrix of dependence values of inherent circumstances

\begin{tabular}{|c|c|c|c|c|c|c|c|}
\hline & $\mathbf{K}_{1}$ & $\mathrm{~K}_{2}$ & $\ldots$ & $\mathrm{K}_{\mathrm{l}}$ & $\ldots$ & $\mathrm{K}_{\mathrm{k}}$ & $\mu_{i}$ \\
\hline$X_{1}$ & $\mu_{11}$ & $\mu_{12}$ & $\ldots$ & $\mu_{11}$ & $\ldots$ & $\mu_{1 k}$ & $\frac{1}{k} \sum_{l=1}^{k} \mu_{1 l}=\mu_{1}$ \\
\hline$X_{2}$ & $\mu_{21}$ & $\mu_{22}$ & $\ldots$ & $\mu_{21}$ & $\ldots$ & $\mu_{2 \mathrm{k}}$ & $\frac{1}{k} \sum_{l=1}^{k} \mu_{2 l}=\mu_{2}$ \\
\hline$\ldots$ & $\ldots$ & $\ldots$ & $\cdots$ & $\ldots$ & $\ldots$ & $\ldots$ & $\ldots$ \\
\hline$X_{i}$ & $\mu_{11}$ & $\mu_{\mathrm{L}}$ & $\ldots$ & $\mu_{i}$ & $\ldots$ & $\mu_{\mathrm{k}}$ & $\frac{1}{k} \sum_{l=1}^{k} \mu_{i l}=\mu_{i}$ \\
\hline$\ldots$ & $\ldots$ & $\ldots$ & $\ldots$ & $\ldots$ & $\ldots$ & $\ldots$ & $\ldots$ \\
\hline$X_{m}$ & $\mu_{\mathrm{ml}}$ & $\mu_{\mathrm{mL}}$ & $\ldots$ & $\mu_{\mathrm{m}}$ & $\ldots$ & $\mu_{n x}$ & $\frac{1}{k} \sum_{l=1}^{k} \mu_{m l}=\mu_{m}$ \\
\hline
\end{tabular}

Priklausomumo reikšmių skaičiavimas vykdomas pagal matricą ( 1 lent.), kurioje $X_{i}$ - alternatyvu aibé, kur $(i=1, \ldots, m), \mu_{i l}$ - atitinkamo kriterijaus $K_{l}$ priklausomumo reikšmé.

Kiekvienai alternatyvai apskaičiuojamas priklausomumo laipsnis $\mu_{i}$. Šiuo atveju ginama nuomoné, kad sprendinys su aritmetiniu vidurkiu (Laplaso kriterijus) (4) yra tinkamas:

$$
\mu_{i}=\frac{1}{k} \sum_{l=1}^{k} \mu_{i l} .
$$

2 pakopa. Pirmojoje pakopoje buvo apibendrintos I žaidejo strategijos. Antrojoje pakopoje tas pats turi būti padaryta II žaidèjui. II žaidejo strategiju aibè ištaip pat reikšta priklausomumo funkcija. Išoriniai dydžiai, galimybių ir aplinkos kriterijai sudaro II žaidèjo strategijų aibę. Jos atvaizduojamos alternatyvu aibe ir užrašomos kaip priklausomumo reikšmémis užpildyta matrica (2 lent.).

3 pakopa. Trečiojoje pakopoje slypi algoritmo esmé. Čia turi būti apibendrinti ir operacionalizuoti abieju pakopu rezultatai.

Kaip buvo minėta, neapibrèžtuju aibių teorija kaip tinkamą operatorių neapibrèžtosios alternatyvų aibès priklausomumo reikšmių matricų (I žaidejo strategijos ir II žaidejo strategijos) sujungimui i vieną neapibréžtụių aibių sprendimų matrica siūlo minimumo operatorių, kadangi rezultatas, tenkinantis abi strategijas, formaliai suprantamas kaip pjūvis per abieju pusių aibes ir pateikiamas vadinamaja pagrindine matrica (3 lent.).

2 lentelè. Išorinių veiksnių priklausomumo reikšmių matrica

Table 2. Matrix of dependence values of outward circumstances

\begin{tabular}{|c|c|c|c|c|c|c|}
\hline & $\mathrm{Y}_{1}$ & $\mathrm{Y}_{2}$ & $\cdots$ & $\mathrm{Y}_{\mathrm{j}}$ & $\cdots$ & $\mathrm{Y}_{\mathrm{n}}$ \\
\hline $\mathrm{X}_{1}$ & $\mu_{11}$ & $\mu_{12}$ & $\cdots$ & $\mu_{1 \mathrm{j}}$ & $\cdots$ & $\mu_{1 \mathrm{n}}$ \\
\hline $\mathrm{X}_{2}$ & $\mu_{21}$ & $\mu_{22}$ & $\cdots$ & $\mu_{2 j}$ & $\cdots$ & $\mu_{2 \mathrm{n}}$ \\
\hline$\cdots$ & $\cdots$ & $\cdots$ & $\cdots$ & $\cdots$ & $\cdots$ & $\cdots$ \\
\hline $\mathrm{X}_{\mathrm{i}}$ & $\mu_{\mathrm{i} 1}$ & $\mu_{\mathrm{i} 2}$ & $\cdots$ & $\mu_{\mathrm{ij}}$ & $\cdots$ & $\mu_{\mathrm{n}}$ \\
\hline$\cdots$ & $\cdots$ & $\cdots$ & $\cdots$ & $\cdots$ & $\cdots$ & $\cdots$ \\
\hline $\mathrm{X}_{\mathrm{m}}$ & $\mu_{\mathrm{n} 1}$ & $\mu_{\mathrm{n} \mathrm{L}}$ & $\cdots$ & $\mu_{\mathrm{nj}}$ & $\cdots$ & $\mu_{\mathrm{nn}}$ \\
\hline
\end{tabular}

lš šios matricos (3 lent.) formuojama galutinè sprendimo prièmimo matrica, vadinamoji neapibrèžtoji žaidimų matrica, kur $\mu_{i j}^{*}=\operatorname{Min}\left(\mu_{i}, \mu_{i j}\right)$ yra neapibrèžtosios skaičiavimụ aibès priklausomumo funkcijos. Sprendimas vyksta minimaksiškumo principu, t. y. iš neapibrèžtosios skaičiavimu aibès priklausomumo funkcijų, pateiktų pagrindinejje sprendimo prièmimo matricoje, reikšmių išrenkama maksimali reikšmè. Sprendimas pateikiamas matricos forma (4 lent.). 
3 lentelè. Pagrindinè sprendimo prièmimo matrica

Table 3. General decision-making matrix

\begin{tabular}{|c|c|c|c|c|c|c|}
\hline & $Y_{1}$ & $Y_{2}$ & $\ldots$ & $Y_{j}$ & $\ldots$ & $Y_{n}$ \\
\hline$\left(x_{1}, \mu_{1}\right)$ & $\operatorname{Min}\left(\mu_{1}, \mu_{11}\right)$ & $\operatorname{Min}\left(\mu_{1}, \mu_{12}\right)$ & $\cdots$ & $\operatorname{Min}\left(\mu_{1}, \mu_{1 j}\right)$ & $\ldots$ & $\operatorname{Min}\left(\mu_{1}, \mu_{1 \mathrm{n}}\right)$ \\
\hline$\left(x_{2}, \mu_{2}\right)$ & $\operatorname{Min}\left(\mu_{2}, \mu_{31}\right)$ & $\operatorname{Min}\left(\mu_{2}, \mu_{22}\right)$ & $\ldots$ & $\operatorname{Min}\left(\mu_{2}, \mu_{2 j}\right)$ & $\cdots$ & $\operatorname{Min}\left(\mu_{2}, \mu_{2 n}\right)$ \\
\hline$\ldots$ & $\ldots$ & $\cdots$ & $\cdots$ & $\ldots$ & $\ldots$ & $\cdots$ \\
\hline$\left(x_{i}, \mu_{i}\right)$ & $\operatorname{Min}\left(\mu_{i}, \mu_{i 1}\right)$ & $\operatorname{Min}\left(\mu_{\mathrm{i}}, \mu_{\mathrm{i}}\right)$ & $\ldots$ & $\operatorname{Min}\left(\mu_{i}, \mu_{i j}\right)$ & $\ldots$ & $\operatorname{Min}\left(\mu_{i}, \mu_{n}\right)$ \\
\hline$\cdots$ & $\ldots$ & $\cdots$ & $\cdots$ & $\cdots$ & $\cdots$ & $\cdots$ \\
\hline$\left(x_{10}, \mu_{n}\right)$ & $\operatorname{Min}\left(\mu_{m}, \mu_{m 1}\right)$ & $\operatorname{Min}\left(\mu_{m}, \mu_{m m^{2}}\right)$ & $\cdots$ & $\operatorname{Min}\left(\mu_{n,}, \mu_{n y}\right)$ & $\cdots$ & $\operatorname{Min}\left(\mu_{m}, \mu_{m n}\right)$ \\
\hline
\end{tabular}

1 variantas. Trisluoksnis silikatiniụ plytu mūras. Vidinè atitvaros dalis -250 mm silikatinių plytų mūras, apšiltinamasis sluoksnis akmens vatos $(130 \mathrm{~mm})$, irengiamas $40 \mathrm{~mm}$ oro tarpas, apdailinama skaldytu silikatinių plytu $68 \mathrm{~mm}$ storio mūru.

2 variantas. Trisluoksnis mūras. Vidinè atitvaros dalis - $190 \mathrm{~mm}$ silikatiniu blokelių mūras, apšiltinamasis sluoksnis akmens vatos $(130 \mathrm{~mm})$, irengiamas 40

\section{Modelio praktinis pritaikymas}

Uždavini galètume formuluoti taip. Reikia ivertinti keletą projektuojamų individualiu gyvenamujų namụ variantụ. Užsakovui yra svarbu namo dydis, naudojamų medžiagų, atliekamų darbų kokybè ir kiek imanoma mažesnè statybos bei eksploatavimo kaina. Projektuotojai pasiūlè penkis iš principo skirtingus variantus ir kiekvienam variantui pasiūlè po keturis išorinių sienų variantus. Taigi turime ivertinti dvidešimt alternatyvų.

Visuose variantuose numatyta stogus dengti bitumo čerpèmis ir apšiltinti $20 \mathrm{~cm}$ storio akmens vatos sluoksniu, taip pat plastikiniai langai su dvigubu stiklo paketu. Visose alternatyvose grindys ant grunto apšiltinamos $5 \mathrm{~cm}$ storio putų polistirolo sluoksniu. Pamatai numatyti surenkamieji, cokolis apšiltinamas 10 $\mathrm{cm}$ storio putų polistirolo sluoksniu. Numatyti keturi skirtingi išorinių sienų variantai:

4 lentelè. Neapibrèžtoji žaidimų sprendimu prièmimo matrica

Table 4. Decision-making in fuzzy games matrix

\begin{tabular}{|c|c|c|c|c|c|c|c|}
\hline & $Y_{1}$ & $Y_{2}$ & $\cdots$ & $Y_{j}$ & $\cdots$ & $Y_{n}$ & $\operatorname{Min}-\max$ \\
\hline$X_{1}$ & $\mu^{*}{ }_{11}$ & $\mu_{12}^{*}$ & $\cdots$ & $\mu^{*}{ }_{1,}$ & $\cdots$ & $\mu^{*}{ }_{11}$ & $\min \left(\mu^{*}{ }_{111}\right)$ \\
\hline $\mathrm{X}:$ & $\mu^{* *}$ & $\mu_{22}^{*}$ & $\cdots$ & $\mu_{2,}^{*}$ & $\cdots$ & $\mu_{2 n}^{*}$ & $\min \left(\mu_{2 n}\right)$ \\
\hline$\cdots$ & $\cdots$ & $\ldots$ & $\cdots$ & $\cdots$ & $\cdots$ & $\ldots$ & $\cdots$ \\
\hline$X_{1}$ & $\mu^{*}{ }_{\mathrm{il}}$ & $\mu^{*}$ & $\cdots$ & $\mu^{*}$ & $\cdots$ & $\mu^{*}$ & $\min \left(\mu^{*}{ }_{n}\right)$ \\
\hline$\ldots$ & $\cdots$ & $\ldots$ & $\cdots$ & $\cdots$ & $\cdots$ & $\cdots$ & $\ldots$ \\
\hline$X_{11}$ & $\mu^{*}{ }_{\mathrm{m} t}$ & $\mu^{*}{ }_{\mathrm{mL}}$ & $\ldots$ & $\mu_{m j}^{*}$ & $\ldots$ & $\mu^{*}{ }_{1 \mathrm{n}}$ & $\min \left(\mu^{*}{ }_{m}\right)$ \\
\hline
\end{tabular}

$\mathrm{mm}$ oro tarpas, apdailinama skaldytu silikatinių plytų $68 \mathrm{~mm}$ storio mūru.

3 variantas. Dujų silikato $400 \mathrm{~mm}$ storio blokelių mūras siūles užpildant specialiais (mažo šilumos laidumo) klijais bei aptinkuojant išorinę atitvaros dalị specialiu (vadinamuoju šiltu) tinku.

4 variantas. Vidine atitvaros dalis $-250 \mathrm{~mm}$ silikatinių plytų mūras, apšiltinama pagal firmos „Termosnaigè" technologiją. Mūras iš išorinès atitvaros pusès apšiltinamas $80 \mathrm{~mm}$ storio akmens vatos sluoksniu ịrengiant medinị karkasą, kuris aptaisomas dar vienu apšiltinamuoju sluoksniu, kuri sudaro $7 \mathrm{~mm}$ faneros sluoksnis, $30 \mathrm{~mm}$ putų poliuretano sluoksnis bei keraminès apdailos plytelès.

Variantų kainos apskaičiuotos neįvertinant sklypo kainos bei apdailos kainos. Bendri alternatyvas aprašantys duomenys pateikti 5 lenteleje. Remiantis aprašytu modeliu duomenys skirstomi $\mathfrak{i}$ vadinamuosius vidinius ir išorinius sistemos itakos veiksnius. Pastatų fizinès charakteristikos (plotas, tūris), kurias užsakovas siekia maksimizuoti, laikysime vidiniais sistemos itakos veiksniais (6 lentelè). Remdamiesi (1)-(4) formulèmis sudarome priklausomumo reikšmių matricą bei ivertiname kiekvienos alternatyvos priklausomumą. Skaičiavimų rezultatai pateikiami 7 lentelèje.

Tokius veiksnius, kaip objekto kaina bei eksploatavimo kaina, kuriuos užsakovas nori minimizuoti ir kurie tampa tam tikru apribojimu, laikysime išoriniais sistemos itakos veiksniais (8 lentelè).

Šiuo etapu nustatome priklausomumo reikšmes išoriniams sistemos itakos veiksniams (taip pat pagal (1)-(4) formules) ir sudarome išorinių veiksniụ priklausomumo reikšmių matricą (9 lentelè). 


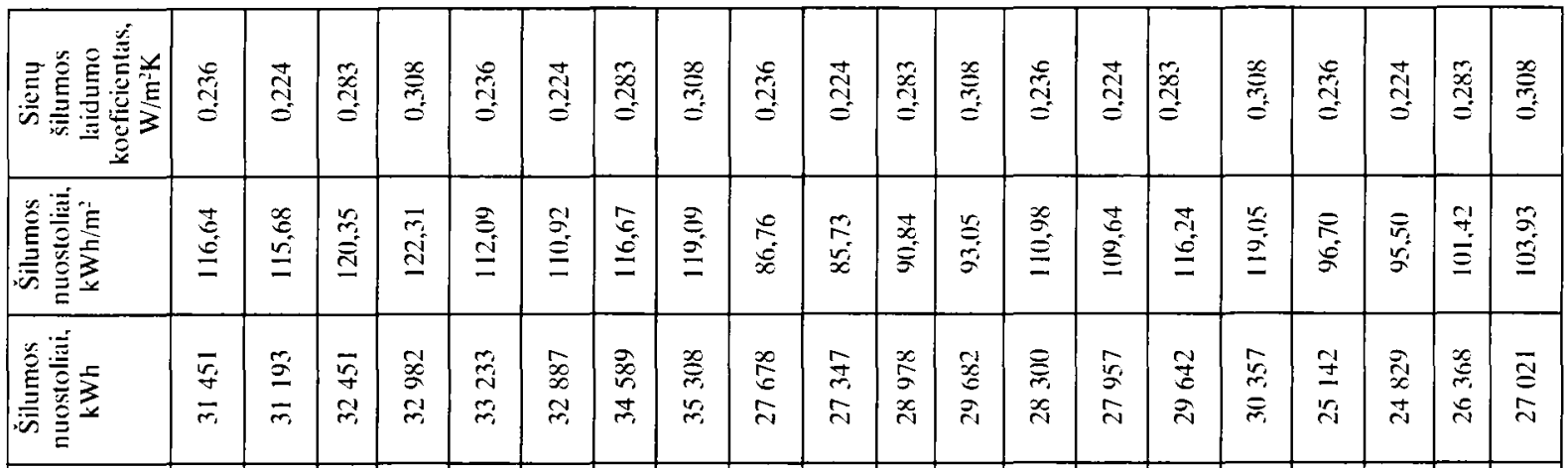

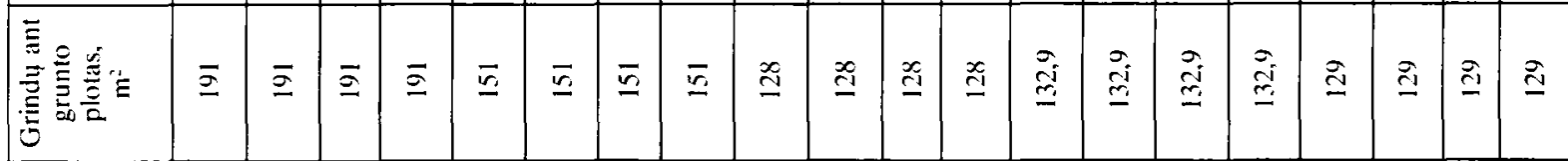

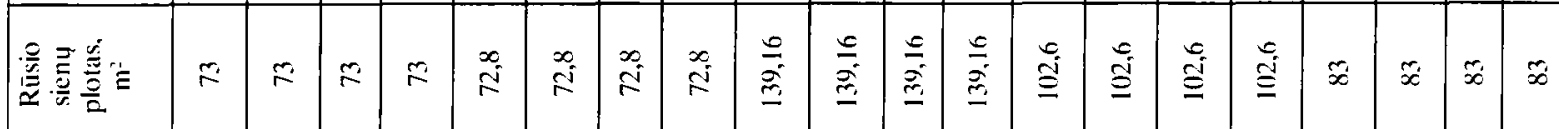

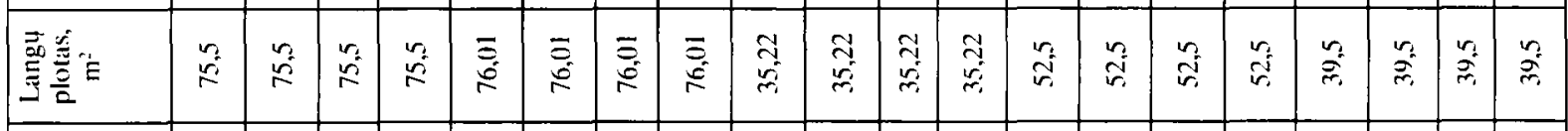

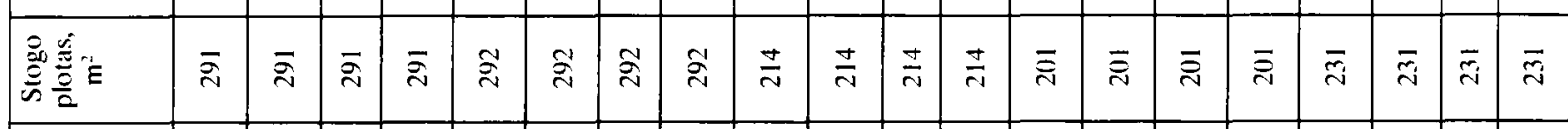

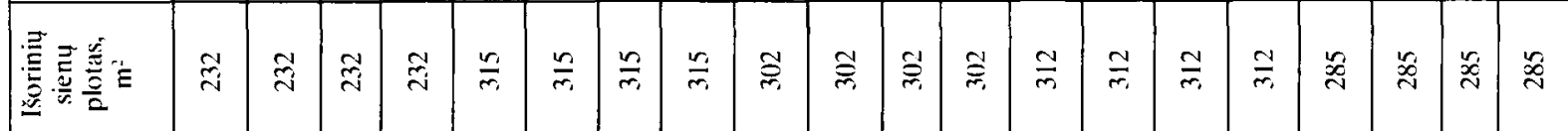

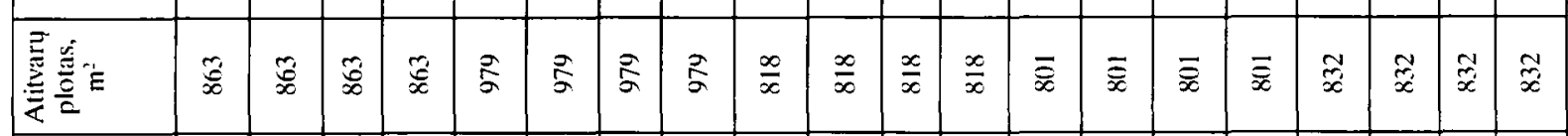

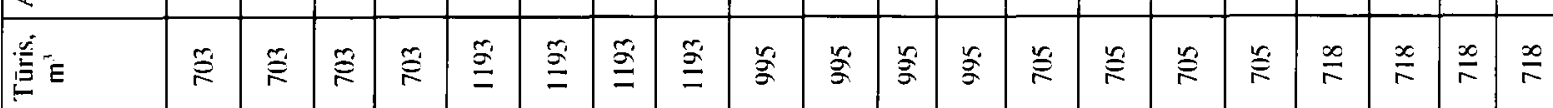

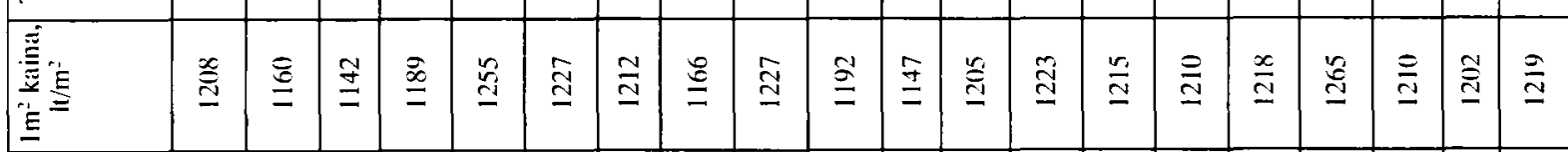

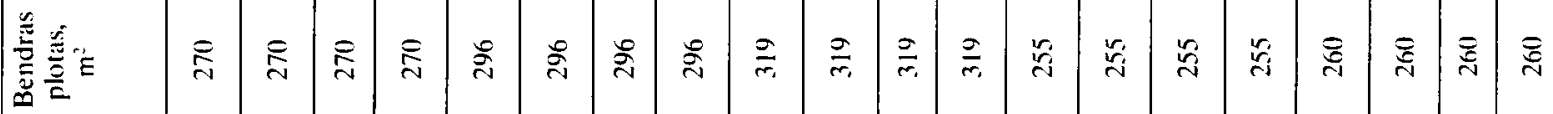

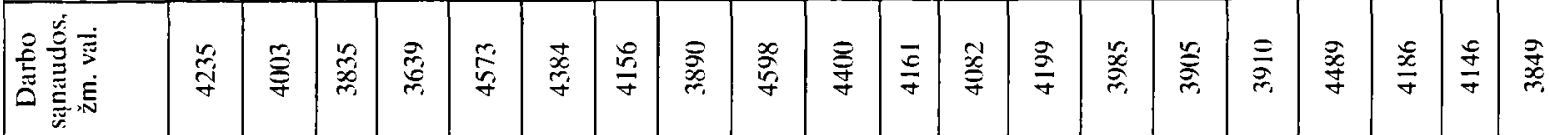

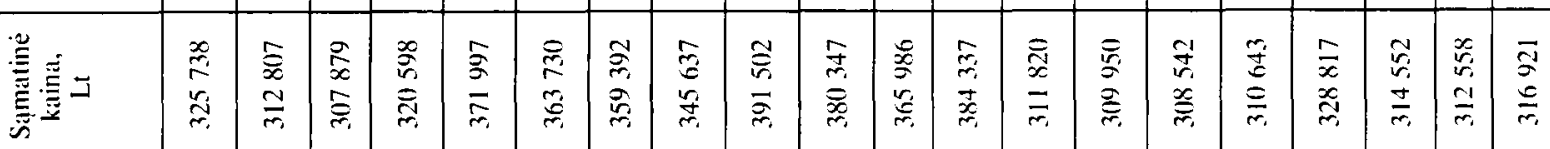

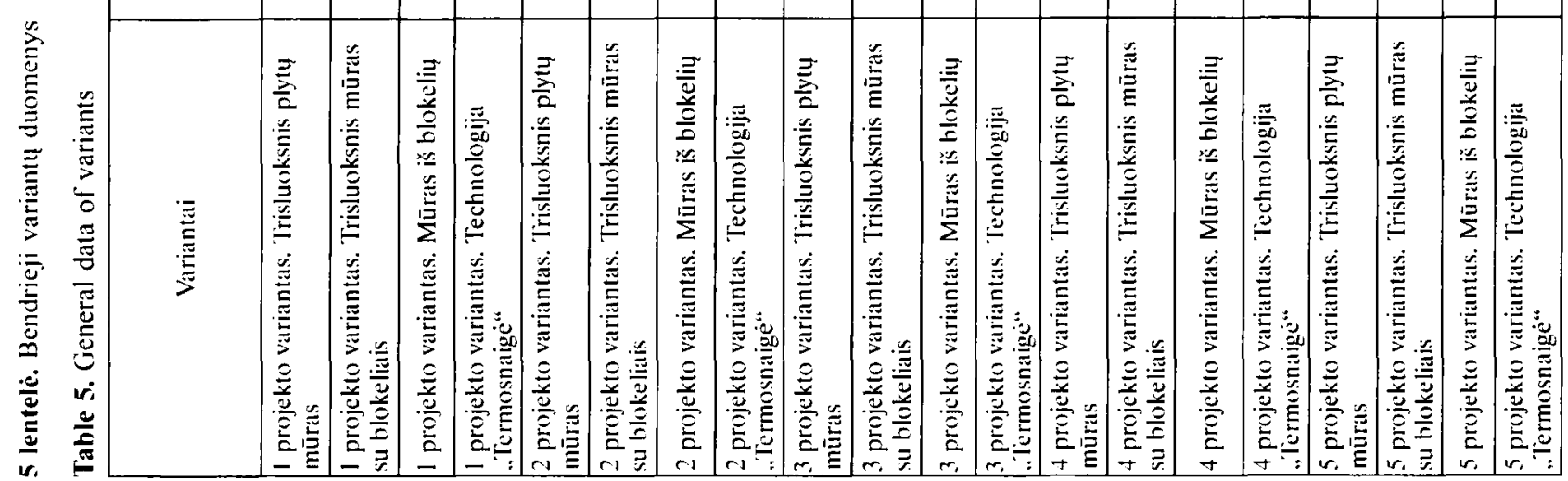


6 lentelè. Vidiniai sistemos įtakos veiksniai

Table 6. Inherent influence circumstances of system

\begin{tabular}{|c|c|c|c|c|c|c|c|c|}
\hline Variantai & $\begin{array}{c}\text { Bendras } \\
\text { plotas, } \\
\mathrm{m}^{2}\end{array}$ & $\begin{array}{c}\text { Türis, } \\
\mathrm{m}^{3}\end{array}$ & $\begin{array}{c}\text { Atitvaru } \\
\text { plotas, } \\
\mathrm{m}^{2}\end{array}$ & $\begin{array}{c}\text { Išoriniụ } \\
\text { sieny } \\
\text { plotas, } \\
\mathrm{m}^{2} \\
\end{array}$ & $\begin{array}{c}\text { Stogo } \\
\text { plotas, } \\
\mathrm{m}^{2}\end{array}$ & $\begin{array}{c}\text { Langu } \\
\text { plotas, } \\
\mathbf{m}^{2}\end{array}$ & $\begin{array}{c}\text { Rūsio } \\
\text { sienụ } \\
\text { plotas, } \\
\mathrm{m}^{2}\end{array}$ & $\begin{array}{c}\text { Grindu } \\
\text { ant grunto } \\
\text { plotas, } \\
\mathrm{m}^{2} \\
\end{array}$ \\
\hline 1 projekto variantas. Trisluoksnis plytụ müras & 270 & 703 & 863 & 232 & 291 & 75,5 & 73 & 191 \\
\hline 1 projekto variantas. Trisluoksnis mūras su blokeliais & 270 & 703 & 863 & 232 & 291 & 75,5 & 73 & 191 \\
\hline 1 projekto variantas. Mūras iš blokeliụ & 270 & 703 & 863 & 232 & 291 & 75,5 & 73 & 191 \\
\hline 1 projekto variantas. Technologija .,Termosnaige“ & 270 & 703 & 863 & 232 & 291 & 75,5 & 73 & 191 \\
\hline 2 projekto variantas. Trisluoksnis plytụ mūras & 296 & 1193 & 979 & 315 & 292 & 76,01 & 72,8 & 151 \\
\hline 2 projekto variantas. Trisluoksnis mūras su blokeliais & 296 & 1193 & 979 & 315 & 292 & 76,01 & 72,8 & 151 \\
\hline 2 projekto variantas. Mūras iš blokelių & 296 & 1193 & 979 & 315 & 292 & 76,01 & 72,8 & 151 \\
\hline 2 projekto variantas. Technologija ...Termosnaige“ & 296 & 1193 & 979 & 315 & 292 & 76,01 & 72,8 & 151 \\
\hline 3 projekto variantas. Trisluoksnis plytu mūras & 319 & 995 & 818 & 302 & 214 & 35,22 & 139,16 & 128 \\
\hline 3 projekto variantas. Trisluoksnis mūras su blokeliais & 319 & 995 & 818 & 302 & 214 & 35,22 & 139,16 & 128 \\
\hline 3 projekto variantas. Mūras iš blokeliụ & 319 & 995 & 818 & 302 & 214 & 35,22 & 139,16 & 128 \\
\hline 3 projekto variantas. Technologija .,Termosnaige“ & 319 & 995 & 818 & 302 & 214 & 35,22 & 139,16 & 128 \\
\hline 4 projekto variantas. Trisluoksnis plytu mūras & 255 & 705 & 801 & 312 & 201 & 52,5 & 102,6 & 132,9 \\
\hline 4 projekto variantas. Trisluoksnis mūras su blokeliais & 255 & 705 & 801 & 312 & 201 & 52,5 & 102,6 & 132,9 \\
\hline 4 projekto variantas. Mūras iš blokeliụ & 255 & 705 & 801 & 312 & 201 & 52,5 & 102,6 & 132,9 \\
\hline 4 projekto variantas. Technologija „Termosnaige“ & 255 & 705 & 801 & 312 & 201 & 52,5 & 102,6 & 132,9 \\
\hline 5 projekto variantas. Trisluoksnis plytu mūras & 260 & 718 & 832 & 285 & 231 & 39,5 & 83 & 129 \\
\hline 5 projekto variantas. Trisluoksnis mũras su blokeliais & 260 & 718 & 832 & 285 & 231 & 39,5 & 83 & 129 \\
\hline 5 projekto variantas. Mũras iš blokelių & 260 & 718 & 832 & 285 & 231 & 39,5 & 83 & 129 \\
\hline 5 projekto variantas. Technologija ..Termosnaige““ & 260 & 718 & 832 & 285 & 231 & 39,5 & 83 & 129 \\
\hline$a_{o}$ & 255 & 703 & 801 & 232 & 201 & 35,22 & 72,8 & 128 \\
\hline$a_{d}$ & 287 & 948 & 890 & 273,5 & 246,5 & 55,615 & 105,98 & 159,5 \\
\hline$a_{m}$ & 319 & 1193 & 979 & 315 & 292 & 76,01 & 139,16 & 191 \\
\hline
\end{tabular}

7 lentelè. Vidinių sistemos jtakos veiksnių priklausomumo reikšmiu matrica

Table 7. Matrix of inherent influence dependence circumstances system

\begin{tabular}{|c|c|c|c|c|c|c|c|c|}
\hline K1 & $\mathrm{K} 2$ & K3 & $\mathrm{K} 4$ & K5 & K6 & K7 & $\mathrm{K} x$ & $\mu_{i}$ \\
\hline 0.139 & $0.000)$ & 0.279 & $0,(00)$ & $1,(\mathbf{X O})$ & $1 .(M(N)$ & $0,(0) 0$ & $1,0(0)$ & 0.427 \\
\hline 0.139 & $0,000)$ & 0,279 & $0,(00)$ & $1,000)$ & $1,(0)$ & $0,(\mathbf{X )})$ & $1,(0) K)$ & 0.427 \\
\hline 0,139 & $0,(K M)$ & 0,279 & $0,000)$ & $1,(0)$ & $1,0(0)$ & $0,(0) 0)$ & $1,(00)$ & 0.427 \\
\hline 0,139 & $0,000)$ & 0.279 & $0,(00)$ & $1,(0)$ & $1,(100)$ & $0,0 \% 0)$ & $1 .(10)$ & 0,427 \\
\hline 0,705 & $1,(\mathbf{M O})$ & $1,(000)$ & $1,(00)$ & $1,(00)$ & $1,(00)$ & $0,(0)$ & 0,303 & 0.751 \\
\hline 0.705 & $1,000)$ & 1,(KO) & $1,(6)$ & $1,000)$ & $1,(\mathbf{M O})$ & $0,(0) 0$ & 0,303 & 0.751 \\
\hline 0.705 & $1,(00)$ & $1,(\mathrm{KO})$ & $1.0 \% 0$ & $1,(0 K)$ & $1,(\mathbf{K K})$ & $0,(K)$ & 0,303 & 0.751 \\
\hline 0.705 & $1,(\mathrm{KOO})$ & I,(K)O & $1.000)$ & $1 .(00)$ & $1 .(00)$ & $0 .(0) 0$ & 0,3013 & 0,751 \\
\hline $1.0(0)$ & 0.642 & 0,026 & 0,934 & 0,055 & $0.000)$ & $1,0 \% 0)$ & $0,000)$ & 0.457 \\
\hline $1 .(K)$ & 0.642 & 0,026 & 0,934 & 0,055 & $0,(K K)$ & $1,000)$ & $0,(X)$ & 0,457 \\
\hline $1.0(x)$ & 0.642 & 0.026 & 0.934 & 0.055 & $0,(K K)$ & $1,(0 \%)$ & $0 .(X)$ & 0,457 \\
\hline $1.0(x)$ & 0.642 & 0,126 & 0.934 & 0,055 & $0,(K K)$ & $1,(0) 0$ & $0,(06)$ & 0.457 \\
\hline $0 .(1)(X)$ & $0.00(0)$ & $0 .(N)$ & 0,996 & $0,0 \times K)$ & 0,386 & 0.424 & 0.017 & 0,228 \\
\hline $0 .(10)$ & $0 .(0)(x)$ & $0,(\mathrm{HO})$ & 0,996 & $0.060)$ & 0.386 & 0,424 & 0,017 & 0.228 \\
\hline $0 .(x)$ & $0.000)$ & $0,(\mathrm{KX})$ & 0,996 & $0.0(K)$ & 0.386 & 0,424 & 0.017 & $0.22 x$ \\
\hline $0.0(1)$ & $0 .(0) 0$ & $0,0(x)$ & 0,996 & $0,0 K()$ & 0,386 & 0,424 & 0.017 & 0.228 \\
\hline 0.017 & 0.003 & 0,080 & 0.703 & 0.254 & 0,031 & 0,064 & $0,(k) 1$ & 0.144 \\
\hline 0.017 & $0 .(6) 3$ & 0,080 & 0.703 & 0,254 & 0.031 & 0.064 & $0 .(k) 1$ & 0.144 \\
\hline 0.017 & 0.013 & $0,0 \times 0$ & 0,703 & 0,254 & 0,031 & 0.064 & $0,(0) 1$ & 0.144 \\
\hline 0,017 & 0,0013 & $0,0,180$ & 0,703 & 0,254 & 0,031 & 0,064 & 0.001 & 0.144 \\
\hline
\end{tabular}


8 lentelè. Išoriniai sistemos įtakos veiksniai

Table 8. Outward influence circumstances of system

\begin{tabular}{|c|c|c|c|c|c|c|}
\hline Variantai & $\begin{array}{c}\text { Sạmatinè } \\
\text { kaina, } \\
\text { Lt }\end{array}$ & $\begin{array}{c}\text { Darbo } \\
\text { sạnaudos, } \\
\text { żm. val. } \\
\end{array}$ & $\begin{array}{c}1 \mathrm{~m}^{2} \\
\text { kaina } \\
1 \mathrm{t} / \mathrm{m}^{2}\end{array}$ & $\begin{array}{c}\text { Šilumos } \\
\text { nuostoliai, } \\
\text { kWh }\end{array}$ & $\begin{array}{c}\text { Šilumos } \\
\text { nuostoliai, } \\
\text { Wh/m }\end{array}$ & $\begin{array}{c}\text { Išoriniụ sienụ } \\
\mathrm{U}, \\
\mathrm{W} / \mathrm{m}^{2} \mathrm{~K} \\
\end{array}$ \\
\hline 1 projekto variantas. Trisluoksnis plytų mūras & 325738 & 4235 & 1208 & 31451 & 116,64 & 0,236 \\
\hline 1 projekto variantas. Trisluoksnis mūras su blokeliais & 312807 & 4003 & 1160 & 31193 & 115,68 & 0,224 \\
\hline 1 projekto variantas. Mūras iš blokeliụ & 307879 & 3835 & 1142 & 32451 & 120,35 & 0,283 \\
\hline 1 projekto variantas. Technologija ..Termosnaige““ & 320598 & 3639 & 1189 & 32982 & 122,31 & 0,308 \\
\hline 2 projekto variantas. Trisluoksnis plytụ mūras & 371997 & 4573 & 1255 & 33233 & 112,09 & 0,236 \\
\hline 2 projekto variantas. Trisluoksnis mūras su blokeliais & 363730 & 4384 & 1227 & 32887 & 110,92 & 0,224 \\
\hline 2 projekto variantas. Mūras iš blokeliụ & 359392 & 4156 & 1212 & 34589 & 116,67 & 0,283 \\
\hline 2 projekto variantas. Technologija ..Termosnaige“" & 345637 & 3890 & 1166 & 35308 & 119,09 & 0,308 \\
\hline 3 projekto variantas. Trisluoksnis plytu mūras & 391502 & 4598 & 1227 & 27678 & 86,76 & 0,236 \\
\hline 3 projekto variantas. Trisluoksnis mūras su blokeliais & 380347 & 4400 & 1192 & 27347 & 85,73 & 0,224 \\
\hline 3 projekto variantas. Mūras iš blokeliụ & 365986 & 4161 & 1147 & 28978 & 90,84 & 0,283 \\
\hline 3 projekto variantas. Technologija ..Termosnaige“ & 384337 & 4082 & 1205 & 29682 & 93,05 & 0,308 \\
\hline 4 projekto variantas. Trisluoksnis plytu mūras & 311820 & 4199 & 1223 & 28300 & 110,98 & 0,236 \\
\hline 4 projekto variantas. Trisluoksnis mūras su blokeliais & 309950 & 3985 & 1215 & 27957 & 109,64 & 0,224 \\
\hline 4 projekto variantas. Mūras iš blokelių & 308542 & 3905 & 1210 & 29642 & 116,24 & 0,283 \\
\hline 4 projekto variantas. Technologija ..Termosnaige“" & 310643 & 3910 & 1218 & 30357 & 119,05 & 0,308 \\
\hline 5 projekto variantas. Trisluoksnis plytų mūras & 328817 & 4489 & 1265 & 25142 & 96,70 & 0,236 \\
\hline 5 projekto variantas. Trisluoksnis müras su blokeliais & 314552 & 4186 & 1210 & 24829 & 95,50 & 0,224 \\
\hline 5 projekto variantas. Mūras iš blokeliụ & 312558 & 4146 & 1202 & 26368 & 101,42 & 0,283 \\
\hline 5 projekto variantas. Technologija „Termosnaige““ & 316921 & 3849 & 1219 & 27021 & 103,93 & 0,308 \\
\hline$a_{0}$ & 307879 & 3639 & 1142 & 24829 & 85.73 & 0,224 \\
\hline$a_{d}$ & 349691 & 4119 & 1203 & 30068 & 104,02 & 0,266 \\
\hline$a_{m}$ & 391502 & 4598 & 1265 & 35308 & 122,31 & 0,308 \\
\hline
\end{tabular}

9 lentelè. Išorinių sistemos ịtakos veiksniu priklausomumo reikšmiu matrica

Table 9. Matrix of outward influence dependence circumstances system

\begin{tabular}{|c|c|c|c|c|c|}
\hline $\mathrm{Y1}$ & $\mathrm{Y} 2$ & $\mathrm{Y} 3$ & $\mathrm{Y} 4$ & $\mathrm{Y} 5$ & $\mathrm{Y} 6$ \\
\hline $0.8 \times 3$ & 0.321 & 0.442 & 0.307 & 0.065 & 0.945 \\
\hline 0,990 & 0,677 & 0.940 & 0.341 & 0,087 & $1.000)$ \\
\hline $1,0(0)$ & 0.892 & $1.0(0)$ & 0.182 & $0 .(0) 8$ & 0.213 \\
\hline 0,938 & $1,(00)$ & 0,671 & 0,126 & $0,(0) 0$ & 0.000 \\
\hline 0.138 & 0,002 & 0.019 & 0.102 & 0.191 & 0.945 \\
\hline 0.258 & 0.127 & 0.226 & 0.135 & 0.230 & 1.6060 \\
\hline 0.329 & 0.441 & 0.392 & 0.013 & 0.064 & 0.213 \\
\hline 0.572 & 0.830 & 0.901 & $0.0(10)$ & 0,022 & $0 .(00)$ \\
\hline $0.0(0)$ & $0 .(0)(0)$ & 0.222 & $0 . \times 18$ & 0.998 & 0.945 \\
\hline 0.049 & 0,110 & 0.632 & 0.855 & I.(KO) & 1.0000 \\
\hline 0.222 & 0.434 & 0.994 & 0.654 & 0.947 & 0.213 \\
\hline 0,021 & 0,557 & 0,481 & 0.555 & 0,896 & $0.0(0)$ \\
\hline 0.994 & 0.375 & 0.269 & 0.744 & 0.228 & 0.945 \\
\hline 0,998 & 0.703 & 0.353 & 0,786 & 0,277 & $1.0(10)$ \\
\hline 1.000$)$ & 0.812 & 0.418 & 0.561 & 0.073 & 0.213 \\
\hline 0,997 & 0.806 & 0,321 & 0.459 & 0.022 & $0.0(x)$ \\
\hline $0 . \times 43$ & 0.036 & $0 .(0 \times)$ & 0.997 & 0.784 & 0.945 \\
\hline 0,982 & 0.395 & 0.420 & I.(KK) & 0.824 & $1.0(0)$ \\
\hline 0.991 & 0.456 & 0.513 & 0.942 & 0.606 & 0.213 \\
\hline 0.967 & 0.877 & 0.313 & 0.887 & 0,504 & $0 .(10)$ \\
\hline
\end{tabular}


10 lentelè. Pagrindiné sprendimo prièmimo matrica

Table 10. General decision-making matrix

\begin{tabular}{|c|c|c|c|c|c|c|c|c|}
\hline Variantai & $\mu_{i}$ & Y1 & Y2 & Y3 & Y4 & Y5 & Y6 & Minimaksiškumas \\
\hline 1 projekto variantas. Trisluoksnis plytų mūras & 0,427 & 0,427 & 0,321 & 0,427 & 0,307 & 0,065 & 0,427 & 0,065 \\
\hline 1 projekto variantas. Trisluoksnis mūras su blokeliais & 0,427 & 0,427 & 0,427 & 0,427 & 0,341 & 0,087 & 0,427 & 0,087 \\
\hline 1 projekto variantas. Mūras iš blokeliụ & 0,427 & 0,427 & 0,427 & 0,427 & 0,182 & 0,008 & 0,213 & 0,008 \\
\hline 1 projekto variantas. Technologija „Termosnaige“" & 0,427 & 0,427 & 0,427 & 0,427 & 0,126 & 0,000 & 0,000 & 0,000 \\
\hline 2 projekto variantas. Trisluoksnis plytu mūras & 0,751 & 0,138 & 0,002 & 0,019 & 0,102 & 0,191 & 0,751 & 0,002 \\
\hline 2 projekto variantas. Trisluoksnis mūras su blokeliais & 0,751 & 0,258 & 0,127 & 0,226 & 0,135 & 0,230 & 0,751 & 0,127 \\
\hline 2 projekto variantas. Mūras iš blokeliụ & 0,751 & 0,329 & 0,441 & 0,392 & 0,013 & 0,064 & 0,213 & 0,013 \\
\hline 2 projekto variantas. Technologija ..Termosnaige“ & 0,751 & 0,572 & 0,751 & 0,751 & 0,000 & 0,022 & 0,000 & 0,000 \\
\hline 3 projekto variantas. Trisluoksnis plytu mūras & 0,457 & 0,000 & 0,000 & 0,222 & 0,457 & 0,457 & 0,457 & 0,000 \\
\hline 3 projekto variantas. Trisluoksnis mūras su blokeliais & 0,457 & 0,049 & 0,110 & 0,457 & 0,457 & 0,457 & 0,457 & 0,049 \\
\hline 3 projekto variantas. Mūras iš blokelių & 0,457 & 0,222 & 0,434 & 0,457 & 0,457 & 0,457 & 0,213 & 0,213 \\
\hline 3 projekto variantas. Technologija ..Termosnaige“ & 0,457 & 0,021 & 0,457 & 0,457 & 0,457 & 0,457 & 0,000 & 0,000 \\
\hline 4 projekto variantas. Trisluoksnis plytu mūras & 0,228 & 0,228 & 0,228 & 0,228 & 0,228 & 0,228 & 0,228 & 0,228 \\
\hline 4 projekto variantas. Trisluoksnis mūras su blokeliais & 0,228 & 0,228 & 0,228 & 0,228 & 0,228 & 0,228 & 0,228 & 0,228 \\
\hline 4 projekto variantas. Mūras iš blokeliụ & 0,228 & 0,228 & 0,228 & 0,228 & 0,228 & 0,073 & 0,213 & 0,073 \\
\hline 4 projekto variantas. Technologija „Termosnaige“" & 0,228 & 0,228 & 0,228 & 0,228 & 0,228 & 0,022 & 0,000 & 0,000 \\
\hline 5 projekto variantas. Trisluoksnis plytų mūras & 0,144 & 0,144 & 0,036 & 0,000 & 0,144 & 0,144 & 0,144 & 0,000 \\
\hline 5 projekto variantas. Trisluoksnis mūras su blokeliais & 0,144 & 0,144 & 0,144 & 0,144 & 0,144 & 0,144 & 0,144 & 0,144 \\
\hline 5 projekto variantas. Mūras iš blokelių & 0,144 & 0,144 & 0,144 & 0,144 & 0,144 & 0,144 & 0,144 & 0,144 \\
\hline 5 projekto variantas. Technologija .,Termosnaige“ & 0,144 & 0,144 & 0,144 & 0,144 & 0,144 & 0.144 & 0,000 & 0,000 \\
\hline \multicolumn{8}{|l|}{ Maksimali reikšmé } & 0,228 \\
\hline
\end{tabular}

Kadangi tarp minètu veiksnių grupių susidaro konfliktinè situacija, yra logiškas anksčiau aprašyto modelio naudojimas taikant minimumo operatoriu $\mu_{A \cap B}(x)=\operatorname{Min}\left[\mu_{A}(x), \mu_{B}(x)\right]$. Taigi kitu etapu sudaroma pagrindinè sprendimo prièmimo matrica (10 lentelè). Iš neapibrèžtosios skaičiavimu aibès priklausomumo funkcijų, pateiktų pagrindinéje sprendimo prièmimo matricoje, reikšmių išrenkama maksimali reikšmé. Skaičiavimai parodè, kad šiuo atveju, atsižvelgiant $\mathfrak{i}$ keliamus tikslus bei esamas galimybes, iš pasiūlytu alternatyvų yra du optimalūs variantai, t. y. šiu alternatyvu priklausomumas pagrindinei sprendimų aibei yra didžiausias.

\section{Išvados}

Modelio pritaikymo sritis - variantų vertinimas, pvz., statybos ir technologiniu metodu parinkimas, mechanizavimo sprendimas, organizaciniai vietos parinkimo sprendimai ir statybos aikštelès irengimo variantu parinkimas, statybos objektu ivertinimas.

Optimalumu laikomos pjūviụ aibés, susidedančios iš dviejų kokybès požymių klasių, t. y. vidiniụ ir išorinių veiksnių, kurie vertinami atitinkamai pagal ju priklausomumo funkcijas, reikšmès.
Ši analizè rodo, kad sisteminiai sprendimai lemia sprendimụ kokybès augimą, visgi dèl informacijos stokos ir kompleksiškumo reikia matematinio apdorojimo. Veiksniai arba parametrai, kuriais remiantis priimamas sprendimas, sujungiami i dvi parametru grupes.

Tokioje situacijoje šią neaiškią informaciją apdoroti padeda tik neapibrèžtujų aibių teorija. Objektyviai egzistuojančių neapibrėžtumų modeliavimas priimant sprendimus vyksta praplečiant klasikines matematines sąvokas neapibrèžtumo sąvokomis. Šio algoritmo optimalumo sq̨voka remiasi dvieju kokybès požymiu klasiu pjūvio aibe.

Kaip šių tyrimų išvados pateikiamos šios pastabos:

1. Sistemiškas sprendimas - naujas sprendimo būdas statybos srityje, kai, atsižvelgiant $i$ visas statybos fazes (planavimą, projektavimą, vykdyma, naudojimą), pasiekiamas aukštas kompleksiškumo lygis, kuris efektyviai leidžia keisti sprendimo lankstumą.

2. Kompetentingai skirstant itakos veiksnius arba vertinimo parametrus pagal du aspektus (vidinius išorinius) imanoma atskleisti sprendimo užduoties konfliktini pobūdi, kuri galima interpretuoti žaidimu teorija ir vertinti taikant neapibrèžtujų aibių teoriją. 


\section{Literatūra}

1. E. K. Zavadskas, A. Kaklauskas. Pastatu sistemotechninis jvertinimas. V.: Technika, 1996. 280 p.

2. J. Ester. Systemanalyse und mehrkriterielle Entscheidung. 1 Auflage. Verlag Berlin, 1987. 231 p.

3. K. D. Schwab. Ein auf dem Konzept der unscharfen Mengen basierendes Entscheidungsmodell bei mehrfacher Zielsetzung. TH Aachen, 1983. $177 \mathrm{p}$.

4. Ю. Блех, У. Гетце. Инвестиционные расчеты. Калининград: Янтар. сказ, 1997. 450 с.

5. Л. Заде. Понятие лингвистической переменной и его применение к принятию приближенных решений. М.: Мир, 1976. 171 c.

6. H. J. Zimmermann, J. Angstenberger. Fuzzy Technologien: Prinzipien, Werkzeuge, Potentiale. VDI-Verlag Gmbh, Dūsseldorf, 1993. 245 p.

7. P. Kortmann. Fuzzy-Modelle zur Systemidentifikation. Ortschrittberichte VDI, Reihe 8: Mess-, Steuerungs- und Regelungstechnik. 1997. $150 \mathrm{p}$.

8. H. H. Bothe. Fuzzy Logic. Berlin-Heidelberg: SpringerVerlag, 1997. $297 \mathrm{p}$.

Iteikta 20000629

\section{THEORY OF FUZZY SETS IN DECISION-MAKING SYSTEMS OF BUILDING MANAGEMENT}

\section{P. Gaučas, E. K. Zavadskas}

S u m mary

The task of decision-making in constructing industry becomes more difficult because of rapid technical upgrowth According to aims, circumstances and opportunity decisions are determined. Disagreement situation arises at this point. Uprising opportunities and influence of circumstances of aims, they are often contradicting each other. Constructing a building, one must look for decision of more favourable conditions for situation and minimum expenditure, but to guarantee a high reliability, so disagreement situation arises. Exacting requirements of quality logically are bound up with expensive realisation [4]. Decision must be optimum and as much as possible satisfy "goodness" indications of decision. However, "goodness" valuation is indefinite conception and disobeys black-and-white logic [Zadeh]. In this case one can understand decision like a conflict in the game theory, where the information is not always defined. To solve the problem the fuzzy sets theory can be used. Using the game theory, elements can be formulated indefinitely and a new model can be made [3]. Trying to estimate the aims of conflicts, the circumstances that influence the decision are divided into two groups. The first group - circumstances of inherent influence - defines what a decision-maker must attain (for example, to maximise quality) and describes strategy of the first player. The second group - circumstances of outward influence - defines what a decision-maker must estimate as a limitation (for example, to minimise price) and describes strategy of the second player. Dependence between inherent and outward circumstances in this step is formed.
There is no clear limit in fuzzy sets theory between dependence (circumstance 1) and independence (circumstance 0 ) of elements on definite set. Dependence degree of element $\mathrm{x}$ on $\mathrm{A}$ set, is described by $\mu_{A}(x)$ function (1), (2).

The valuation in fuzzy sets theory takes place at three levels. At the first level meanings of dependence on inherent circumstances are calculated (1), (2), and matrix is determined (Fig 2). According to formula (3), dependence degree on each alternative is calculated. In the second level meanings of dependence on outward circumstances are calculated according to the formula (1), (2) and the matrix is filled in (Fig 3).

At the third level the results of first two levels are summed. Using operator of minimum general matrix of decisions-making is determined (Fig 4), According to the general matrix, the indefinite matrix of decision-making is determined (Fig 5). Minimax principle makes the decision.

The received result is optimal, because it satisfies the aim causing the conflict. In the paper, the example of a private house is selected, using the described method.

This method may be used to make decisions, when the task is of conflicting character. Competently distributing circumstances of influence or parameters of valuation by two aspects (inherent and outward) it can be explained the mean of conflicting character, and interpretation using the described method can be made.

Paulius GAUČAS. PhD student. Dept of Building Technology and Management. Vilnius Gediminas Technical University, Saulètekio al. 11, LT-2040 Vilnius, Lithuania. E-mail: Gaucas@hotmail.com

A graduate of Vilnius Gediminas Technical University. MSc (1997). Research visits to Leipzig Higher School of Technology, Economics and Culture (Germany, 1997, 1999). Research interests: new decision-making model of fuzzy sets method.

Edmundas Kazimieras ZAVADSKAS. Doctor Habil, Professor, Rector of Vilnius Gediminas Technical University. Member of Lithuania Academy of Sciences, Member of Ukrainian Academy of Technological Cybernetics. Vilnius Gediminas Technical University, Saulètekio al. 11, LT-2040 Vilnius, Lithuania. E-mail: Rector $a$ adm.vtu.lt

In 1973 Dr degree in building structures. Assistant, Senior Assistent. Associate Professor, Professor at the Dept of Construction Technology and Management. In 1987, Dr Habil at Moscow Civil Engineering Institute (building technology and management). Research visits to Moscow Civil Engineering Institute, Leipzig and Aachen Higher Technical Schools. He maintains close academic links with the universities of Aalborg (Denmark), Salford and Glamorgan (UK), Poznan University of Technology (Poland), Leipzig Higher School of Technology. Economics and Culture (Germany). Member of international organisations. Member of steering and programme committees of many international conferences. Member of editorial boards of some research journals. Author of monographs in Lithuanian. English, German and Russian. Research interests: building technology and management, decision-making theory, automation in design, expert systems. 